\title{
PENGARUH NORMA SUBYEKTIF, DAN TAM TERHADAP NIAT MENGGUNAKAN SISTEM ERP
}

\author{
Rizki Endah Susilaputri \\ Universitas Airlangga Surabaya \\ rizkiendahsusilaputri@gmail.com
}

\begin{abstract}
ERP is a system used by the company to integrate all business processes. This study aimed to determine the effect of Subjective Norm and Technology Acceptance Model (TAM) of the Intention to Use ERP Systems. TAM in this study was measured by two indicators: Perception Perceived Usefulness and Ease of Use. Respondents in this study were users of ERP systems on PT. Semen Gresik (Persero), Tbk. Questionnaires were the primary data used in this research and random sampling was used as data collection method. Questionnaires were distributed about 70 copies but only 63 were returned, and 3 of them were incomplete questionnaires. The data analysis technique used was Partial Least Square, with the help of Smart PLS 2.0 software. The results of this study are: 1) Subjective Norms have positive significant effect on Intention to Use ERP Systems. 2) Perceived Usefulness have positive significant effect on Intention to Use ERP Systems. 3) Perceived Ease of Use have positive significant effect on Intention to Use ERP Systems.
\end{abstract}

Keywords: subjective norm, technology acceptance model, intention to use ERPsystems

\begin{abstract}
ABSTRAK
Sistem ERP adalah sistem yang digunakan oleh perusahaan untuk mengintegrasikan semua proses bisnis. Penelitian ini bertujuan untuk mengetahui pengaruh norma subyektif dan technology acceptance model (TAM) terhadap niat menggunakan sistem ERP. TAM dalam penelitian ini diukur dengan bantuan dua indikator: persepsi kegunaan dan persepsi kemudahan penggunaan. Data yang digunakan adalah data primer dengan menggunakan kuesioner. Metode pengumpulan data, yaitu random sampling. Responden dalam penelitian ini adalah pengguna sistem ERP pada PT. Semen Gresik (Persero), Tbk. Kuesioner didistribusikan 70 eksemplar namun hanya 63 yang dikembalikan, dan 3 kuesioner tidak lengkap. Teknik analisis data yang digunakan adalah Partial Least Square, dengan bantuan software Smart PLS 2.0. Hasil dari penelitian ini adalah: 1) Norma subjektif berpengaruh positif signifikan terhadap niat menggunakan sistem erp. 2) Persepsi kegunaan berpengaruh positif signifikan terhadap Niat Penggunaan Sistem ERP. 3) Persepsi kemudahan penggunaan berpengaruh positif signifikan terhadap Niat Penggunaan Sistem ERP.
\end{abstract}

Kata kunci: norma subjektif, model penerimaan teknologi, niat untuk menggunakan sistem ERP 


\section{PENDAHULUAN}

Pemanfaatan Teknologi Informasi dan Komunikasi dalam lingkungan bisnis telah menjadi kebutuhan bagi setiap perusahaan untuk meningkatkan efisiensi dan efektifitasnya. Salahsatunya ditandai dengan maraknya penerapan sistem ERP pada perusahaan - perusahaan di Indonesia. Enterprise Resource Planning (ERP) adalah sebuah konsep untuk merencanakan dan mengelola sumber daya organisasi agar dapat dimanfaatkan secara optimal untuk menghasilkan nilai tambah bagi seluruh pihak yang berkepentingan atas organisasi tersebut, Falahah (2007). ERP itu sendiri kini mulai digunakan oleh beberapa perusahaan dalam pelaksanaan aktivitas bisnisnya. Dalam penelitian Insite Metrodata (2006) dalam Pontoh (2010),perusahaan - perusahaan di Indonesia yang telah mengimplementasikan sistem ERP untuk perusahaan besar hampir $100 \%$, perusahaan menengah 50\%, dan perusahaan kecil $20 \%$.

Hal ini dapat mensinyalir adanya perkembangan penerapan ERP oleh perusahaan-perusahaan di Indonesia. ERP merupakan sebuah sistem informasi perusahaan yang dirancang untuk mengkoordinasikan semua sumber daya, dan aktifitas yang diperlukan untuk proses bisnis yang lengkap. Faktor utama yang mempengaruhi keberhasilan dalam penerapan sistem ERP adalah sumber daya manusia. Dalam penerapan ERP seringkali terjadi kegagalan atau keterlambatan keberhasilan implementasi sistem ERP yang juga disebabkan oleh faktor manusia. Menurut penelitian Deloitte and Touche dalam Pontoh (2010)terhadap 164 pemakai sistem, dari 62 perusahaan Fortune-500 pengguna sistem ERP yang hasilnya menunjukkan timbulnya permasalahan, $62 \%$ disebabkan oleh faktor manusia, $16 \%$ oleh proses bisnis, dan 12\% oleh teknologi informasi, Brown \& Nasuti(2005). Contoh dari software ERP yang sudah banyak dikenal dan digunakan oleh perusahaan besar yakni SAP (System Application and Product in Data Processing) dan Oracle. Namun dalam penelitian ini, software ERP yang digunakan adalah SAP. 
Model yang digunakan dalam penelitian ini yaitu persepsi kemudahan penggunaan dan persepsi kegunaan. Kedua hal ini merupakan faktor yang terpenting dalam menjelaskan dan memprediksi penerimaan dan penggunaan sistem informasi, Pontoh (2010). Kedua model tersebut biasa disebut Technology Acceptance Model (TAM). TAM merupakan suatu teori yang dapat digunakan untuk mengukur tingkat penerimaan pengguna terhadap teknologi. Menurut Davis, Bagozzi, \& Warshaw, (1989)seseorang berniat untuk menggunakan teknologi baru karena yakin dengan adanya manfaat atau Perceived Usefulness dimana pengguna meyakini dengan menggunakan teknologi baru tersebut akan meningkatkan kinerjanya (Persepsi Kegunaan), seseorang juga berniat menggunakan teknologi baru karena yakin dengan adanya kemudahan penggunaan atau Perceived Ease of Use dimana pengguna meyakini bahwa dengan menggunakan teknologi baru pengguna terhindar dari kesulitan dan dalam artian bahwa teknologi baru tersebut mudah untuk dioperasikan (Persepsi Kemudahan).

Studi ini mengembangkan model TAM dengan menambahkan satu variabel eksternal. Davis et al., (1989)menyebutkan bahwa tingkat penerimaan pengguna teknologi informasi ditentukan oleh beberapa atribut pembangun, diantaranya yaitu variabel dari luar (external variable). Yang dalam penelitian ini yaitu norma subyektif. Sedangkan persepsi pengguna terhadap kemudahan (perceived ease of use) dan persepsi pengguna terhadap manfaat (perceived usefulness) merupakan konstruk dari teori TAM.

Penelitian kali ini membahas tentang pengaruh norma subyektif dan technology acceptance model (TAM) terhadap niat menggunakan sistem ERP, dalam hal ini sistem yang digunakan adalah SAP. Sampel yang digunakan dalam penelitian ini yaitu user sistem SAP pada PT. Semen Gresik (persero), Tbk dengan metode pengumpulan data menggunakan random sampling. Dan teknik analisis data yang digunakan yaitu partial least square. 
Berdasarkan latar belakang yang telah diuraikan, maka penelitian ini diberi judul “Pengaruh norma subyektif, persepsi kemudahan penggunaan, dan persepsi kegunaan terhadap niat menggunakan sistem ERP pada PT. Semen Gresik (Persero), Tbk.”

\section{RERANGKA TEORITIS DAN HIPOTESIS}

\section{Konsep Dasar Norma Subyektif}

Teori yang digunakan acuan dalam penelitian ini yaitu teori tindakan beralasan (TRA) yang dalam hal ini diwakili oleh konstruk norma subyektif dan niat menggunakan sistem ERP. Fishbein and Ajzen (1975: 302) norma subyektif merujuk kepada persepsi seseorang bahwa penting baginya berpendapat berperilaku apa yang seharusnya atau yang tidak seharusnya dilakukan. Norma subyektif ditentukan oleh kepercayaan kepercayaan normative orang lain yang akan mempengaruhi niat untuk melakukan atau tidak melakukan perilaku yang sedang dipertimbangkan, Pontoh (2010). Norma subyektif dalam hal ini yaitu kepatuhan terhadap suatu kebijakan yang berlaku di lingkungan organisasi. Norma subyektif ini penting karena akan meningkatkan niat seseorang untuk melakukan suatu pekerjaan.

\section{Konsep Dasar TAM}

Model penerimaan teknologi atau technology acceptance model (TAM)merupakan suatu teori sistem teknologi informasi yang menunjukkan model penerimaan dan penggunaan sistem teknologi informasi dari sudut pandang pemakai, Pontoh (2010). Technology acceptance model (TAM) dalam hal ini terdiri dari dua konstruk yaitu :

a. Persepsi kegunaan (PG) merupakan sebuah kepercayaan (belief) tentang proses pengambilan keputusan, dalam artian bahwa sistem ERP akan digunakan apabila pengguna percaya bahwa akan memperoleh manfaat.

b. Persepsi Kemudahan Penggunaan (PMP) merupakan suatu kepercayaan pula. Dengan artian bahwa sistem ERP akan digunakan jika pemakai percaya bahwa 
untuk menggunakan sistem ERP itu tidak dibutuhkan usaha yang luar biasa untuk mempelajarinya. Hal ini disebabkan karena sistem tersebut mudah untuk dioperasikan.

\section{Konsep Dasar Sistem ERP}

\section{Definisi ERP}

MenurutPontoh(2010), ERP merupakan paket perangkat lunak (software) yang menjadi sistem inti yang terintegrasi untuk mengelola sumber daya perusahaan dan mendukung sistem-sistem informasi perusahaan. Menurut Dhewanto dan Falahah (2007:2) pengertian ERP berdasarkan singkatan dari Enterprise, Resource, and Planning, mencerminkan sebuah konsep bahwa:

a. Planning, yang berarti bahwa ERP menekankan pada aspek perencanaan yang terintegrasi di suatu organisasi/perusahaan, bersifat lintas fungsional, terdiri dari fitur yang dapat merencanakan dan mengelola sumber daya organisasi dengan lebih efisien dan dapat merespon kebutuhan pelanggan dengan lebih baik.

b. Enterprise, digambarkan sebagai sebuah kelompok orang dengan tujuan tertentu yang memiliki sumber daya untuk mencapai tujuan tersebut.

c. Resources, dapat berupa asset perusahaan yang meliputi asset keuangan, sumber daya manusia, konsumen, pemasok, teknologi, dan strategi.

\section{Manfaat dan Fungsi Sistem ERP}

Manfaat utama sekaligus kelebihan dari ERP ini yaitu dapat mengintegrasikan berbagai proses bisnis perusahaan,Pontoh(2010). Amoako-Gyampah \& Salam(2004)beberapa manfaat ERP yaitu:

a) ERP mengintegrasikan dan menyinkronisasikan semua aktivitas perusahaan sehingga keberadaan sistem ERP dipercaya dapat lebih cepat menanggapi konsumen, mengurangi waktu siklus dan meningkatkan produktivitas.

b) Integrasi sistem informasi ERP juga meniadakan banyak sumber data, meniadakan banyak masukan data dan menyediakan data yang lebih akurat dan tepat waktu. 
c) Memfasilitasi arus informasi dan komunikasi diantara unit-unit organisasi yang berbeda.

\section{Sejarah Evolusi Sistem ERP}

Pada 1970-an, perusahaan tidak lagi dihadapkan pada masalah persediaan. Sistem informasi produksi yang dirancang untuk mengatur operasi perusahaan manufaktur telah ada, yang kemudian dikenal dengan nama Material requirements Planning (MRP), Rao Siriginidi (2000). Sistem MRP merupakan sistem yang merencanakan permintaan material untuk memproduksi barang. Material yang diperlukan diidentifikasi berdasarkan setiap item barang yang akan diproduksi. Sistem ini tergantung pada bill of material dan master production schedule (Pontoh, 2010). Dengan demikian,fokus sistem ini pada jadwal order material yang diperlukan untuk produksi yang diminta dan diadakan (Rao Siriginidi, 2000).

Pada 1980-an, MRP dikembangkan lagi menjadi manufacturing resources planning (MRP II)(Rao Siriginidi, 2000). MRP II merupakan sistem yang merencanakan produksi barang dengan memasukkan seluruh komponen produksi seperti mesin-mesin dan manusia, berarti bukan hanya perencanaan material seperti pada sistem MRP. Kekurangan dari sistem MRP II yakni belum terintegrasi(Pontoh, 2010).

Pada 1990-an, muncul enterprise resource planning (ERP) yangmengintegrasikan seluruh subsistem-subsistem yang ada di perusahaan(Pontoh, 2010). Sehingga dapat disimpulkan bahwa sistem ERP merupakan pengembangan dari sistem MRP dan MRP II.

Salah satu sistem ERP yang banyak digunakan oleh perusahaan-perusahaan besar di Indonesia yaitu SAP(system analysis and program development). SAP adalah perusahaan software terbaik keempat di dunia yang berdiri sejak 1972 dan berpusat di Jerman. SAP mengembangkan standar aplikasi perangkat lunak untuk waktu proses bisnis yang nyata. 


\section{Gambar 1.1}

History of ERP System

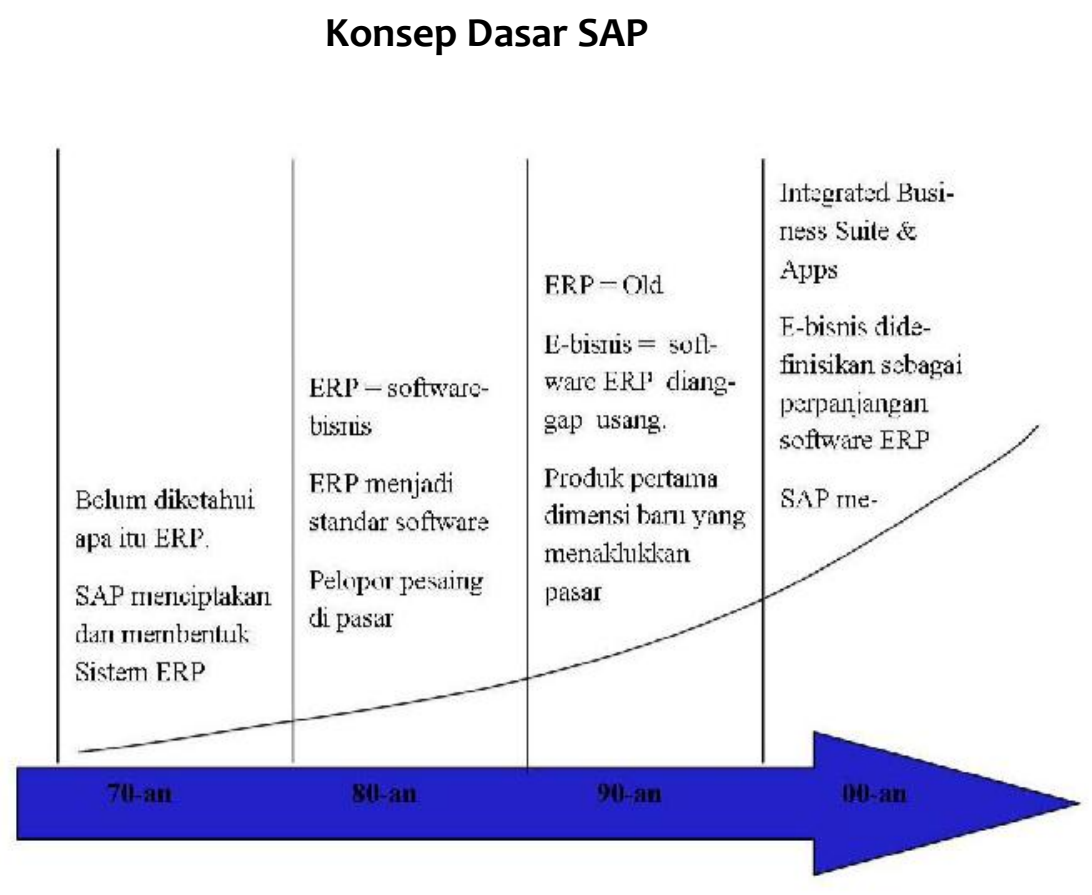

Pada tahun 1970-an, konsep ERP belum dikenal oleh masyarakat. Dengan sistem $\mathrm{R} / 1$, SAP mengembangkan produk perangkat lunak yang mengolah data dengan waktu proses yang nyata dan tersimpan pada database pusat.

Pada tahun 1980-an, sistem ini dikenal sebagai standard dalam sistem ERP. Sejak SAP dikenal oleh masyarakat luas, perusahaan SAP menjadi penguasa pasar. Proses yang terintegrasi menyebabkan peningkatan efisiensi dan mempersingkat reaksi terhadap kejadian tak terduga.

Pada tahun 1990-an, internet mulai berkembang. Perusahaan-perusahaan baru mengembangkan aplikasi-aplikasi dengan internet dan ekonomi baru. Perusahaan tersebut biasanya memiliki karyawan yang sedikit dan hanya mengandalkan internet saja. Pasar berubah karena pertumbuhan internet. Perusahaan mulai terlibat secara langsung antara satu sama lain. 
Kerangka pemikiran yang mendasari penelitian ini dapat digambarkan sebagai berikut:

\section{Gambar 1.2}

\section{Kerangka Pemikiran}

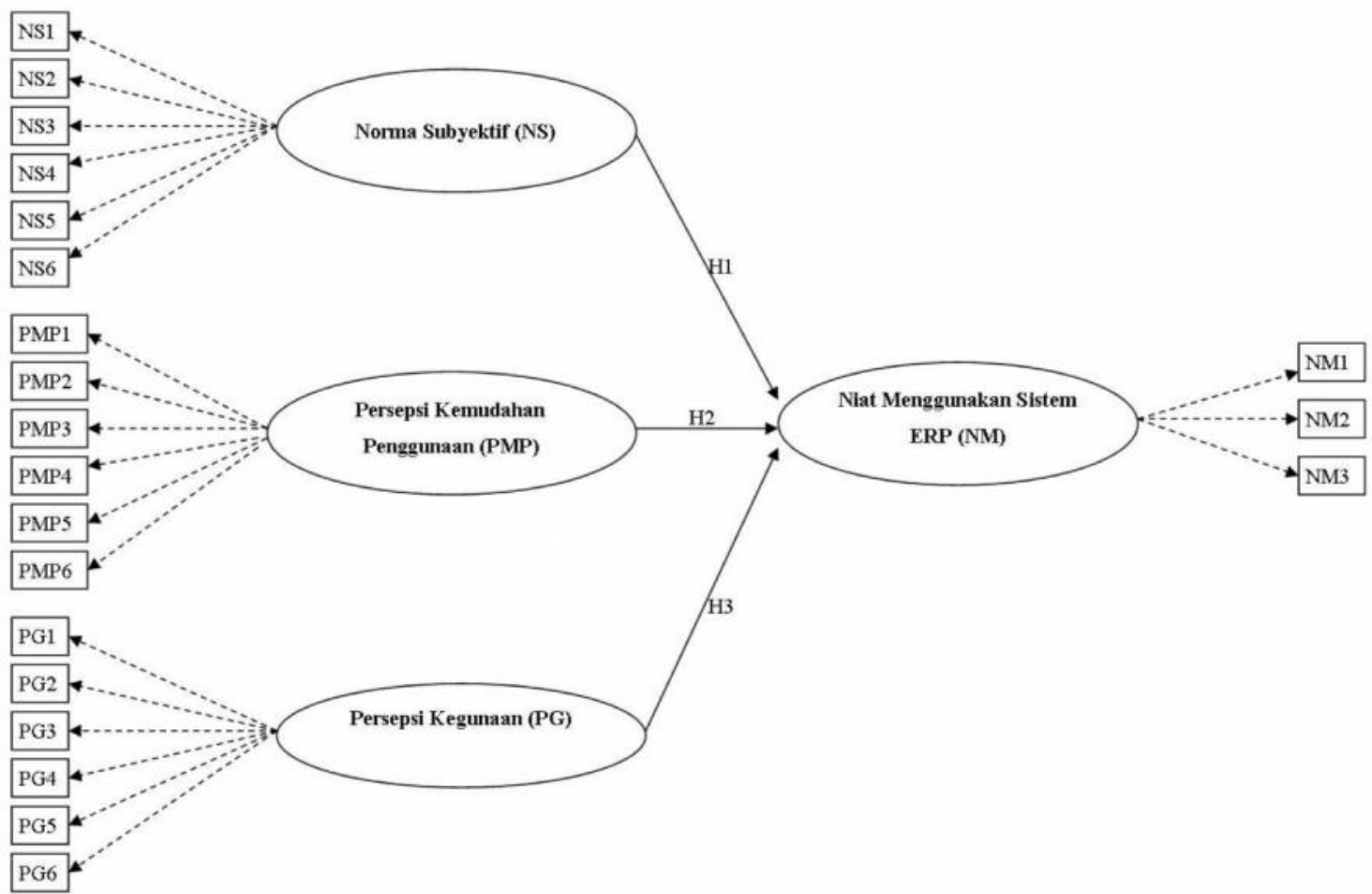

\section{Pengaruh Norma Subyektif terhadap Niat Menggunakan Sistem ERP}

Norma subyektif diharapkan dapat mempengaruhi niat menggunakan sistem ERP. Teori yang digunakan dalam hal ini yaitu TRA atau biasa kita kenal sebagai teori tindakan beralasan, dimana norma subyektif mempengaruhi niat menggunakan sistem ERP ini berdasarkan kepatuhan terhadap suatu peraturan atau kebijakan yang berlaku. Norma subyektif yaitu suatu tekanan sosial individu untuk melakukan atau tidak melakukan suatu perilaku tertentu. Tekanan sosial dalam hal ini yaitu tentang penggunaan sistem ERP dalam suatu perusahaan. Sistem ERP merupakan sistem mandatory sehingga mau tidak mau, semua karyawan dalam perusahaan tersebut harus menggunakan sistem ERP. Tekanan yang dihadapi oleh para karyawan 
mempengaruhi niat karyawan untuk menggunakan sistem ERP. Dimana dalam hal ini tekanan sosial tersebut berupa kepatuhan terhadap kebijakan yang digunakan oleh perusahaan. Dengan demikian, norma subyektif diharapkan dapat memberikan pengaruh terhadap niat menggunakan sistem ERP melalui tekanan sosial yang dihadapi.

\section{Pengaruh Persepsi Kemudahan Penggunaan terhadap Niat Menggunakan Sistem ERP}

Persepsi kemudahan penggunaan (PMP) diharapkan dapat mempengaruhi niat menggunakan sistem ERP. Teori yang digunakan dalam studi ini yaitu teori technology acceptance model (TAM) yang terdiri dari dua konstruk yaitu persepsi kemudahan penggunaan dan persepsi kegunaan. Persepsi kemudahan penggunaan yaitu suatu kepercayaan dimana jika suatu sistem digunakan, maka pemakai sistem akan merasa bahwa untuk menggunakan sistem tersebut tidak perlu proses pembelajaran yang terlalu serius, karena sistem tersebut mudah untuk dipelajari. Selain itu, jika suatu sistem ini digunakan maka pemakai akan merasa perkerjaannya lebih ringan dibanding tanpa bantuan sistem. Sistem ERP dalam hal ini SAP, akan digunakan apabila pemakai mempercayai bahwa untuk menggunakan sistem tersebut pengguna tidak perlu proses pembelajaran yang panjang. Keyakinan bahwa sistem ERP mudah untuk dipelajari dan meringkankan pekerjaannya mempengaruhi niat karyawan untuk menggunakan sistem ERP. Dengan demikian persepsi kemudahan penggunaan diharapkan mempengaruhi niat menggunakan sistem ERP.

\section{Pengaruh Persepsi Kegunaan terhadap}

\section{Niat Menggunakan Sistem ERP}

Persepsi kegunaan (PG) diharapkan dapat mempengaruhi niat menggunakan system ERP. Teori yang digunakan sebagai dasar dalam hal ini yaitu technology acceptance model (TAM). Persepsi kegunaan yaitu suatu kepercayaan dimana jika suatu sistem digunakan, maka akan memberikan manfaat bagi pemakainya. Pemakai sistem akan merasa bahwa dengan menggunakan system tersebut maka pekerjaan 
akan lebih cepat selesai dan tingkat ketepatan dalam pekerjaan akan lebih baik dari pada tanpa menggunakan sistem. Keyakinan bahwa system ERP memberikan manfaat bagi penggunanya mempengaruhi niat pengguna untuk menggunakan sistem ERP yang dalam hal ini yaitu SAP. Dengan demikian persepsi kegunaan diharapkan mempengaruhi niat menggunakan sistem ERP.

Berdasarkan latar belakang dan rumusan masalah yang diajukan dalam penelitian ini, maka dapat disusun hipotesis penelitian sebagai berikut:

H1: Norma Subyektif Berpengaruh Signifikan terhadap Niat Menggunakan Sistem ERP

H2: Persepsi Kemudahan Penggunaan Berpengaruh Signifikan terhadap Niat Menggunakan Sistem ERP.

H3: Persepsi Kegunaan Berpengaruh Signifikan terhadap Niat Menggunakan Sistem ERP.

\section{METODE}

\section{Rancangan Penelitian}

Penjelasan tentang penelitian ini didasarkan pada beberapa aspek:

1. Jika didasarkan pada tujuan penelitian, jenis penelitian yang digunakan dalam studi ini yaitu penelitian kuantitatif.

2. Jika dilihat dari sumber datanya, penelitian ini menggunakan data primer, dengan menggunakan angket tertutup (kuesioner). Angket berisi pertanyaan dan pilihan jawaban pada suatu perusahaan yang telah mengaplikasikan sistem ERP. Unitanalisisnya meliputi karyawan perusahaan yang telah mengaplikasikan sistem ERP pada proses bisnisnya. Sampling penelitian ini yaitu random sampling dimana semua unit dalam populasi memiliki peluang yang sama untuk dijadikan sampel agar hasilnya dapat digeneralisasikan. 


\section{Identifikasi Variabel}

Berdasarkan kerangka pikir yang telah disusun, variabel yang digunakan sebagai pedoman pembahasan dalam penelitian ini yaitu:

1. Variabel Independen, yang terdiri dari:

- Norma Subyektif

- Persepsi Kemudahan Penggunaan

- Persepsi Kegunaan

2. Variabel dependen yaitu niat menggunakan sistem ERP

\section{Definisi Operasional dan Pengukuran Variabel}

\section{Variabel Independen}

Norma subyektif (NS) yaitu suatu tekanan sosial individu untuk melakukan atau tidak melakukan suatu perilaku tertentu. Tekanan sosial dalam hal ini yaitu tentang penggunaan sistem ERP dalam suatu perusahaan. Sistem ERP merupakan sistem mandatory sehingga mau tidak mau, semua karyawan dalam perusahaan tersebut harus menggunakan sistem ERP. Variabel ini dibantu dengan enam indikator yaitu NS1 NS6.

Persepsi kemudahan penggunaan (PMP) yaitu suatu kepercayaan dimana jika suatu sistem digunakan, maka pemakai sistem akan merasa bahwa untuk menggunakan sistem tersebut tidak perlu proses pembelajaran yang terlalu serius, karena sistem tersebut mudah untuk dipelajari. Selain itu, jika suatu sistem ini digunakan maka pemakai akan merasa perkerjaannya lebih ringan dibanding tanpa bantuan sistem. Sistem ERP dalam hal ini SAP, akan digunakan apabila pemakai mempercayai bahwa untuk menggunakan sistem tersebut pengguna tidak perlu proses pembelajaran yang panjang. Variabel ini dibantu oleh enam indikator yaitu PMP1 PMP6.

Persepsi kegunaan (PG) yaitu suatu kepercayaan dimana jika suatu sistem digunakan, maka akan memberikan manfaat bagi pemakainya. Pemakai sistem akan 
merasa bahwa dengan menggunakan sistem tersebut maka pekerjaan akan lebih cepat selesai dan tingkat ketepatan dalam pekerjaan akan lebih baik daripada tanpa menggunakan sistem. Variabel ini dibantu oleh enam indikator yaitu PG1 - PG6.

Variabel - variabel di atas menggunakan instrument yang diadopsi dari penelitian Pontoh, (2010). Masing-masing variabel dibantu oleh indikator untuk mengukurnya. Indikator diukur dengan menggunakan skala likert dengan 5 pilihan jawaban. Jawaban yang disediakan dimulai dengan sangat tidak setuju (diberi poin 1) sampai dengan sangat setuju (diberi poin 5). Semakin tingi poin angka tersebut menunjukkan semakin tinggi kegunaan yang dirasakan oleh pemakai dalam penggunaan sistem ERP.

Niat menggunakan sistem ERP (NM) yaitu suatu keinginan yang timbul setelah melihat, mengamati, dan membandingkan kegiatan yang dilakukan dengan bantuan suatu objek maupun tidak. Variabel ini dibantu oleh tiga indikator, yaitu indikator NM1 NM3.

\section{Populasi, Sampel, dan Teknik Pengambilan Sampel.}

Populasi pada penelitian ini yaitu pengguna sistem ERP pada PT. Semen Gresik (persero), Tbk dalam hal ini adalah karyawan yang memiliki user. Penelitian ini menggunakan data primer, yaitu data diperoleh dari penyebaran angket yang berisi pertanyaan tertulis. Pengumpulan data pada penelitian ini menggunakan metode simple random, yaitu mengambil secara langsung dari populasi secara random, Jogiyanto (2008).

\section{ANALISIS DATA DAN PEMBAHASAN}

\section{Analisis Model Pengukuran}

Evaluasi model pengukuran dilakukan untuk mengetahui tingkat validitas dan reliabilitas masing - masing indikator dan konstruk yang digunakan dalam penelitian ini. Tahapan dalam mengukur tingkat validitas ada dua tahap yaitu validitas konvergen dan validitas diskriminan. Sedangkan untuk mengukur tingkat reliabilitas dilakukan menggunakan composite reliability. 


\section{a. Analisis Validitas Konvergen (Convergent Validity)}

Convergent validity dapat dievaluasi dengan menggunakan indikator validitas. Indikator validitas dapat dilihat dari nilai loading factor, reliabilitas konstruk, dan nilai Average Variance Extracted (AVE).

Dalam studi ini standar loading factor yang digunakan untuk mengukur konstruk yaitu diatas 0.5, (Yamin \& Kurniawan : 2011). Nilai loading factor yang dihasilkan indikatorNS4 dan NS6 yang mengukur konstruk Norma Subyektif hanya sebesar 0.469 dan 0.161; angka ini tidak valid karena tidak memenuhi standar yaitu $>0.5$ sehingga perlu dikeluarkan dari model. Maka data perlu direvisi dan diolah kembali.

Setelah dilakukan revisi dan diolah kembali, semua indikator telah menunjukkan loading factor diatas 0.5 sehingga dapat dinyatakan valid dan bisa dilakukan proses selanjutnya yaitu menguji signifikansi loading factor dengan $t$ statistic. Tahap ini dapat dilanjutkan dengan melakukan bootstrapping pada model tersebut.Setelah tahapan bootstrapping dilakukan maka akan dapat dilihat hasil t statistic yang dapat digunakan untuk menguji signifikansi loading factor tersebut.

Semua loading factor memiliki nilai $t$ statistic $>1.96$ sehingga jelas data tersebut memiliki validitas yang signifikan. Setelah loading factor yang dihasilkan telah valid dan signifikan, maka selanjutnya dapat dilakukan pengukuran terhadap tingkat validitas dan reliabilitas. Tahap selanjutnya yang dilakukan yaitu menguji reliabilitas konstruk dengan melihat nilai AVE, composite reliability, dan cronbach's alpha.

Standar yang digunakan untuk menilai apakah data tersebut reliabel atau tidak yaitu >0.7. Dari output yang dihasilkan menunjukkan konstruk NS memiliki cronbach's alpha 0.684991; hal ini menunjukan bahwa data tidak reliabel. Namun dalam PLS untuk mengukur tingkat reliabilitas lebih disarankan untuk menggunakan Composite Reliability (Latan \& Ghozali ; 2012). Pada kolom Composite reliability dapat dilihat bahwa nilai untuk masing-masing konstruk menunjukkan angka $>0.7$ sehingga data di atas dapat tetap dinyatakan reliabel. Pengamatan pada nilai AVE dihasilkan menunjukkan 
bahwa konstruk - konstruk tersebut memiliki nilai >0.5 sehingga dapat dinyatakan bahwa konstruk di atas memenuhi syarat validitas konvergen.

\section{b. Analisis Validitas Diskriminan (Discriminant Validity)}

Selanjutnya perlu dilakukan juga evaluasi terhadap discriminant validity dengan dua tahap, yaitu melihat cross loadings dan membandingkan antara nilai kuadrat korelasi antara konstruk dengan nilai AVE atau korelasi antara konstruk dengan akar kuadrat AVE (Yamin \& Kurniawan :2011).

Hasil menunjukkan bahwa setiap konstruk berkorelasi lebih tinggi dengan masing masing indikatornya, sehingga dapat dikatakan bahwa konstruk mampu menjelaskan varian pada setiap indikatornya lebih tinggi indikator konstruk lainnya. Korelasi NM1, NM2, dan NM3 dengan konstruk NM adalah 0.780828; 0.858871; dan 0.848689. Nilai korelasi indikator tersebut lebih tinggi dengan konstrak NM dibandingkan dengan konstrak lainnya. Begitu pula juga dengan korelasi indikator terhadap konstruk lainnya. Sehingga dapat dikatakan bahwa data tersebut memiliki discriminant validitas yang baik.Pemeriksaan selanjutnya yaitu dengan membandingkan antara korelasi konstrak dengan akar kuadrat AVE.

Korelasi maksimal konstruk NM dengan konstruk lainnya yaitu 0.518393; sedangkan akar AVE yaitu 0.8302. Konstruk NS memiliki korelasi maksimal sebesar 0.211178; sedangkan akar AVE yaitu 0.7167. Selengkapnya,setiap konstruk pada tabel 1.3 memiliki nilai akar AVE lebih besar dari korelasi antar konstruk. Maka secara umum semua indikator telah memiliki validity discriminant yang baik dalam menyusunmasing masing variabelnya.

\section{Analisis Model Struktural}

Model struktural dalam PLS diukur dengan menggunakan $R_{2}$ untuk variabel dependen, dan koefisien path yang ditunjukkan dengan t statistics untuk uji signifikansi antar konstruk. Pemeriksaan ini meliputi signifikansi hipotesis dan nilai $R_{2}$. Semakin tinggi nilai $R_{2}$ maka semakin baik hipotesis yang diajukan. Skor koefisien path yang 
ditunjukkan dengan $t$ statistic memiliki standar >1.96 untuk pengujian hipotesis pada alpha (tingkat kesalahan penelitian) sebesar 5\% (Latan \& Ghozali :2012).

\section{a. Analisis R-square}

Berdasarkan pengolahan data menggunakan PLS, nilai koefisien determinasi yang dihasilkan adalah sebagai berikut:

Goodness of fit pada model PLS dapat diketahui dari nilai R2. Semakin tinggi nilai R2 maka dapat dikatakan bahwa model semakin fit dengan data. Nilai R2 pada konstruk NM sebesar 0.344377. Artinya, besarnya pengaruh norma subyektif, persepsi kegunaan, dan persepsi kemudahan penggunaan terhadap niat user untuk menggunakan Sistem ERP sebesar 34.43\%.

\section{b. Uji Kausalitas}

Hasil pengujian hipotesis dapat diperoleh dengan cara membandingkan nilai $t$ statistics dengan standar yang telah ditetapkan yaitu 1.96 .

Berdasarkan Tabel 1.5 menunjukkan bahwa ketiga hipotesis memiliki hubungan jalur yang signifikan. Hal ini dapat dilihat dari hasilt statistic dari masing - masing hipotesisyang menunjukkan angka >1.96.

Dari hasilnya dapat dijelaskan hasil pengujian hipotesis sebagai berikut:

\section{a. Pengaruh norma subyektif terhadap niat menggunakan sistem ERP}

Dapat diketahui bahwa variabel norma subyektif (NS) memiliki pengaruh positif dan signifikan terhadap niat menggunakan sistem ERP (NM). Hal ini ditunjukkan oleh nilai koefisien jalur $(0,235723)$ bertanda positif serta signifikan pada alpha $5 \%$ yang ditunjukkan oleh nilai t statistic adalah sebesar 2.826674 dimana nilai t statistic tersebut lebih besar dari 1.96.

b. Pengaruh persepsi kemudahan penggunaan terhadap niat menggunakan sistem ERP

Dapat diketahui bahwa variabel persepsi kemudahan penggunaan (PMP) memiliki pengaruh positif yang signifikan terhadap niat menggunakan 
sistem ERP (NM). Hal ini ditunjukkan oleh nilai koefisien jalur sebesar 2.073652 dimana nilai t statistic tersebut lebih besar dari 1,96.

\section{c. Pengaruh persepsi kegunaan terhadap niat menggunakan sistem ERP}

Dapat diketahui bahwa variabel persepsi kegunaan (PG) memiliki pengaruh positif yang signifikan terhadap niat menggunakan sistem ERP (NM). Hal ini ditunjukkan oleh nilai koefisien jalur (0.288853) bertanda positif serta signifikan pada alpha 5\% yang ditunjukkan oleh nilai t statistic adalah 2.412593 dimana nilai t statistic tersebut lebih besar dari 1,96.

\section{PEMBAHASAN}

Hasil dari penelitian ini menunjukkan bahwa norma subyektif, persepsi kemudahan penggunaan, dan persepsi kegunaan berpengaruh secara positif dan signifikan terhadap niat menggunakan sistem ERP. Penjelasan dari masing - masing variabel adalah sebagai berikut:

a. Norma Subyektif

Berdasarkan uji model struktural yang dihasilkan menunjukkan bahwa pengaruh norma subyektif sebesar (0.235723) bertanda positif serta signifikan pada alpha $5 \%$ yang ditunjukkan oleh nilai t statistic adalah sebesar 2.826674 terhadap niat menggunakan sistem ERP dimana nilai $t$ statistic tersebut lebih besar dari 1.96.Dengan demikian dapat disimpulkan bahwa norma subyektif (NS) memiliki pengaruh yang positif dan signifikan terhadap niat menggunakan sistem ERP (NM). Maka dapat disimpulkan bahwa dalam studi ini, hipotesis satu (H1) terbukti atau didukung dengan fakta.

Fishbein \& Ajzen(1975),norma subyektif merujuk kepada persepsi seseorang bahwa penting baginya berpendapat berperilaku apa yang seharusnya atau yang tidak seharusnya dilakukan. Norma subyektif ditentukan oleh kepercayaan kepercayaan normative orang lain yang akan mempengaruhi niat untuk melakukan atau tidak melakukan perilaku yang sedang dipertimbangkan (Pontoh :2010). 
Hasil temuan penelitian ini menunjukkan bahwa semakin tinggi norma subyektif, semakin tinggi niat untuk menggunakan sistem ERP. Berarti semakin besar pengaruh orang orang penting dan orang - orang yang berpengaruh seperti atasan langsung dan dewan direksi semakin besar niat pemakai untuk menggunakan sistem ERP melalui kepatuhan.

Studi ini mendukung penelitian (Pontoh : 2010)yang menemukan bahwa norma subyektif memiliki pengaruh secara langsung terhadap niat perilaku melalui kepatuhan untuk sistem mandatori.

b. Persepsi Kemudahan

Penggunaan Berdasarkan uji model struktural yang dihasilkan menunjukkan bahwa pengaruh PMP terhadap NM sebesar (0.256448) bertanda positif serta signifikan pada alpha 5\% yang ditunjukkan oleh nilai t statistic adalah sebesar 2.073652 dimana nilai t statistic tersebut lebih besar dari 1.96. Dengan demikian dapat disimpulkan bahwa persepsi kemudahan penggunaan (PMP) memiliki pengaruh yang positif dan signifikan terhadap niat menggunakan sistem ERP (NM). Maka dapat disimpulkan bahwa dalam studi ini, hipotesis dua ( $\left.\mathrm{H}_{2}\right)$ terbukti atau didukung dengan fakta.

Model penerimaan teknologi merupakan suatu teori sistem teknologi informasi dan penggunaan sistem teknologi informasi dari sudut pandang pemakai Pontoh (2010). Model ini dikembangkan oleh Davis et al. (1989)yang merupakan pengembangan dari teori tindakan beralasan atau theory of reasoned action (TRA). Persepsi kemudahan penggunaan (PMP) merupakan sebuah kepercayaan seseorang bahwa suatu sistem mudah untuk digunakan.sistem ERP akan digunakan jika user percaya bahwa sistem ERP mudah untuk digunakan. Atau kepercayaan user bahwa jika sistem ERP digunakan maka user akan terbebas dari usaha.

Hasil studi ini mendukung model penerimaan teknologi (Technology Acceptance Model atau TAM) dari (Davis et al :1989)yang menyatakan bahwa 
persepsi kemudahan pengunaan secara langsungmempengaruhi niat menggunakan sistem ERP. Teori mereka berpendapat bahwa pemakai percaya bahwa sistem yang mudah dipelajari, dan digunakan, mudah menjadi terampil, jelas, dan dapat dimengerti, dapat dikontrol, dan fleksibel akan menimbulkan niat pemakai untuk memeriksa informasi, mendownload laporan,serta mendapatkan informasi bisnis perusahaan yang berhubungan dengan pekerjaan mereka.

Hasil penelitian ini mendukung model TAM dari (Shih \& Huang : 2009)yang menyatakan bahwa manfaat yang dirasakan kuat dan secara langsung oleh user mempengaruhi niat perilaku, tetapi hanya signifikan dan secara langsung mempengaruhi penggunaan aktual. Namun hasil penelitian ini tidak mendukung penelitian (Pontoh :2010). Penelitian (Pontoh :2010) berpendapat bahwa tidak semua pemakai sistem ERP mempersepsikan bahwa sistem ERP mudah dipelajari dan mudah terampil.

\section{c. Persepsi Kegunaan}

Berdasarkan uji model struktural yang dihasilkan menunjukkan bahwa pengaruh PG terhadap NM sebesar (0.288853) bertanda positif serta signifikan pada alpha 5\% yang ditunjukkan oleh nilai t statistic adalah sebesar 2.412593 dimana nilai tstatistics tersebut lebih besar dari 1.96.Dengan demikian dapat disimpulkan bahwa persepsi kegunaan ( $P G$ ) memiliki pengaruh yang positif dan signifikan terhadap niat menggunakan sistem ERP (NM). Maka dapat disimpulkan bahwa dalam studi ini, hipotesis tiga (H3) terbukti atau didukung dengan fakta.

Persepsi kegunaan (PG) merupakan sebuah kepercayaan bahwa apabila suatu sistem digunakan akan membawa manfaat bagi pekerjaannya.Sistem ERP akan digunakan jika user percaya bahwa sistem ERP tersebut membawa manfaat baginya.

Penelitian ini mendukung model penerimaan teknologi (technology acceptance model atau TAM) dari Davis et al. (1989)yang menyatakan bahwa 
persepsi kegunaan berpengaruh secara langsung terhadap niat menggunakan sistem ERP. Berdasarkan teori mereka, pemakai mempercayaibahwa niat menggunakan sistem ERP bermanfaat, memepercepatdan mempermudah pekerjaan, meningkatkan kinerja dan produktivitas, serta efektif sehingga menimbulkan niat pemakai untuk mendapatkan informasi dan mendownload laporan yang menunjang aktifitas mereka sehari-hari yang berhubungan dengan pekerjaannya. Penelitian ini juga mendukung penelitian Shih \& Huang, (2009)yang menyatakan bahwa persepsi kemudahan penggunaan secara langsung terkena dampak perilaku niat.

\section{SIMPULAN}

Penelitian ini bertujuan untuk mengetahui pengaruh norma subyektif, persepsi kemudahan penggunaan, dan persepsi kegunaan terhadap niat menggunakan system ERP pada PT. Semen Gresik (Persero), Tbk. Sampel penelitian ini yaitu pengguna sistem ERP dalam hal ini SAP pada PT. Semen Gresik (Persero), Tbk.

Berdasarkan pada pembahasan pada bab sebelumnya mengenai pengaruh Norma Subyektif, Persepsi Kemudahan Penggunaan dan Persepsi Kegunaan terhadap Niat untuk Menggunakan Sistem ERP, maka kesimpulan dari penelitian ini adalah sebagai berikut:

a. Pengaruh variabel Norma Subyektif (NS) terhadap Niat Menggunakan Sistem ERP (NM) adalah sebesar 0.235723 bertanda positif dandisignifikan pada alpha 5\% yg ditunjukkan oleh nilai $t$ statistic sebesar 2.826674 dimana nilai $t$ statistic tersebut lebih besar dari 1.96. Dengan demikian dapat disimpulkan bahwa Norma Subyektif (NS) memiliki pengaruh yang signifikan terhadap Niat Menggunakan Sistem ERP (NM).

b. Pengaruh variabel Persepsi Kemudahan Penggunaan (PMP) terhadap Niat Menggunakan Sistem ERP (NM) adalah sebesar 0.256448 bertanda positif serta 
signifikan 5\% yang ditunjukkan olah nilai $t$ statistic sebesar 2.073652 dimana nilai $t$ statistics tersebut lebih besar dari 1.96. Dengan demikian dapat disimpulkan bahwa Persepsi Kemudahan Penggunaan (PMP) memiliki pengaruh yang signifikan terhadap Niat Menggunakan Sistem ERP (NM).

c. Pengaruh variabel Persepsi kegunaan (PG) terhadap Niat Menggunakan Sistem ERP (NM) adalah sebesar 2.88853 bertanda positif serta signifikan 5\% yang ditunjukkan oleh nilai tstatistic sebesar 2.412593 dimana nilai $t$ statistics tersebut lebih besar dari 1.96.Dengan demikian dapat disimpulkan bahwa Persepsi Kegunaan (PG) memilikipengaruh yang signifikan terhadap Niat Menggunakan Sistem ERP (NM).

Keterbatasan penelitian ini adalah sebagai berikut:

a. Pada saat mengukur tingkat validitas indikator NS4 dan NS6 memiliki nilai outer loading 0.469 dan 0.161 sehinggadua indikator tersebut harus dikeluarkan dari model karena tidak memenuhi standar validitas yaitu >0.5. Hal ini mungkin disebabkan indikator yang digunakan kurang dipahami oleh responden.

b. Perusahaan yang digunakan sebagai sampel penelitian menggunakan SAP.Sehingga penelitian ini tidak dapat digeneralisasikan dengan penelitian lain yang menggunakan sampel perusahaan yang menggunakan sistem ERP selain SAP. Mengingat tingkat kesulitan yang berbeda pada masing - masing jenis sistem ERP.

Adapun saran yang dapat diberikan olehpeneliti adalah sebagai berikut:

a. Untuk penelitian selanjutnya diharapkan dapat menggunakan indikator lain untuk variabel norma subyektif untuk menghindari kasus yang sama yaitu data tidak valid.

b. Penelitian selanjutnya diharapkan untuk memperluas populasi sampel. Mungkin bisa dilakukan dengan menambahkan perusahaan lain yang menggunakan sistem ERP yang berbeda. 


\section{PUSTAKA ACUAN}

Hwang, Yujong.2005. "Investigating Enterprise Systems Adoption: Uncertainty Avoidance, Intrinsic Motivation, and the Technology Acceptance Model". European Journal of Information Systems 14, pp 150-161.

Ghozali, Imam. Hengky Latan. 2012. Konsep, Teknik dan aplikasi Smart PLS 2.0 M3. Semarang: Badan Penerbit Universitas Diponegoro.

Widiatmika, I Made. Dana Indra Sensuse. 2012. "Pengembangan Model Penerimaan Teknologi Internet oleh Pelajardengan Menggunakan KonsepTechnology Acceptance Model (TAM)". Jurnal Sistem Informasi MTI-UI. Vol. 4 No. 2.

Mohammad, Mohd. Zulkifli. 2011.AnExploration of Social Networking Sites (SNS) Adoption in Malaysia Using Technology Acceptance Model (TAM), Theory of Planned Behavior (TPB)And Intrinsic Motivation. Journal of Internet Banking and Commerce. vol. 16. no.2.

SAP 01 Fundamental, Participant Handbook .2006. SAP AG.

Venkatesh, Viswanath. 2000. "Determinants of Perceived Ease of Use: Integrating Control, Intrinsic Motivation, and Emotion into the Technology Acceptance Model". Information Systems Research 11, pp 342-365.

Venkatesh, Viswanath. 2003. "User Acceptance of Information Technology: Toward A Unified View”. MIS Quarterly.Vol. 27 No. 3. pp 425 - 478.

Amoako-Gyampah, K.\& Salam, A. F. 2004. An extension of the technology acceptance model in an ERP implementation environment. Information \& Management, 41(6), 731-745.

Brown, W. Nasuti, F. 2005. What ERP systems can tell us about Sarbanes-Oxley. Information Management \& Computer Security, 13(4), 311-327.

Davis, F. D., Bagozzi, R. P., \& Warshaw, P. R. 1989. User acceptance of computer technology: a comparison of two theoretical models. Management science, 35(8), 982-1003.

Falahah, W. D. 2007. ERP Menyelaraskan Teknologi Informasi dengan Strategi Bisnis. Jakarta: Informatika 
Fishbein, M., \& Ajzen, I. 1975. Belief, attitude, intention and behavior: An introduction to research and theory. Reading, PA: Addison-Wesley.

Jogiyanto, H. 2008. Metodologi Penelitian Sistem Informasi. Yogyakarta: Penerbit Andi, 7.

Pontoh, G. T. 2010. Pengaruh faktor-faktor penerimaan terhadap niat pemakai sistem erp dengan budaya Sebagai variabel moderator.

Rao Siriginidi, S. 2000. Enterprise resource planning in reengineering business. Business Process Management Journal, 6(5), 376-391.

Shih, Y.-Y., \& Huang, S.-S. 2009. The actual usage of ERP systems: An extended technology acceptance perspective. Journal of Research and Practice in Information Technology, 41(3), 263.

Yamin, S., \& Kurniawan, H. 2011. Generasi Baru Mengolah Data dengan Partial Least Square Path Modeling. Jakarta: Salemba Infotek, 173. 